\title{
BMJ Open Trends in gambling participation and gambling severity among Finnish men and women: cross-sectional population surveys in 2007, 2010 and 2015
}

\author{
Sari Castrén, ${ }^{1,2,3}$ Maria Heiskanen, ${ }^{4}$ Anne H Salonen ${ }^{1,5}$
}

To cite: Castrén $\mathrm{S}$, Heiskanen M, Salonen AH. Trends in gambling participation and gambling severity among Finnish men and women: cross-sectional population surveys in 2007 , 2010 and 2015. BMJ Open 2018;8:e22129. doi:10.1136/ bmjopen-2018-022129

- Prepublication history for this paper is available online To view these files, please visit the journal online (http://dx.doi org/10.1136/bmjopen-2018022129).

Received 2 February 2018 Revised 29 June 2018 Accepted 17 July 2018

Check for updates

(C) Author(s) (or their employer(s)) 2018. Re-use permitted under CC BY-NC. No commercial re-use. See rights and permissions. Published by BMJ.

${ }^{1}$ The Alcohol, Drugs and Addictions Unit, Department of Public Health Solutions, Nationa Institute for Health and Welfare, Helsinki, Finland

${ }^{2}$ Institute of Clinical Medicine, University and University Hospital of Helsinki, Helsinki, Finland

${ }^{3}$ Department of Psychology and Speech Language Pathology, Faculty of Social Science, University of Turku, Turku, Finland

${ }^{4}$ Problem Gambling Clinic, Helsinki, Finland

${ }^{5}$ Faculty of Health Sciences, University of Eastern Finland Helsinki, Finland

Correspondence to

Dr Sari Castrén;

sari.castren@thl.fi

\section{ABSTRACT}

Objective The aim of this study is to evaluate trends in past-year gambling participation and gambling severity among Finnish men and women from 2007 to 2015.

Design Cross-sectional population surveys from years 2007, 2011 and 2015.

Setting Data were drawn from the population register and collected using computer-assisted telephone interviews. Participants Representative random samples of Finns aged 15-74 were drawn in the study in $2007(n=5008)$, $2011(n=4484)$ and $2015(n=4515)$ with response rates of $58 \%, 40 \%$ and $62 \%$, respectively.

Outcome measures The outcome measures were gambling versatility, type of games, gambling intensity and gambling severity. Significance $(p)$ between time points was determined using $\chi^{2}$ tests. All temporal comparisons between 2007-2011, 2011-2015 and 2007-2015 were performed separately for all respondents aged 15-74 and for women and men.

Results Gambling participation overall showed a rising trend (6.6 percentage points, $95 \% \mathrm{Cl} 4.9$ to 8.3) from 2007 to 2015. In 2007-2011 women's gambling participation increased more (7.8 percentage points, $95 \% \mathrm{Cl} 5.5$ to 10.4 ) than men's (5.4 percentage points, $95 \% \mathrm{Cl} 3.2$ to 7.6$)$. The most popular game types since 2007 have been lottery games, scratch cards and electronic gaming machines (EGMs). EGM gambling, on the other hand, has decreased since 2007. Online gambling has increased significantly from 2007 to 2015 in both genders. Men's at-risk gambling decreased from 2007 to 2011, while women's at-risk gambling and problem gambling increased from 2011 to 2015.

Conclusions Women's increasing gambling participation is causing gender differences in gambling behaviour to narrow. The article concludes with a discussion of the need for gender-specific interventions aimed at preventing gambling-related harm and ultimately at protecting the most vulnerable groups.

\section{INTRODUCTION}

Gambling is historically seen as a predominantly male preserve, but in recent years women's gambling participation has been increasing. ${ }^{1}$ There are marked gender differences in product preferences, gambling
Strengths and limitations of this study

- The key strength of this study is that it assesses gambling trends at three time points between 2007 and 2015, looking separately at the trend for men and women.

- An additional strength of this study is the description of trends with regard to game types gambled between 2007 and 2015.

- The data sets were collected by two different organisations, which partly explains the differences in response rates.

- In regards to some game types identification of trends was not possible (eg, online casino gambling questions in Finnish gambling surveys were different, thus not comparable and cruise ship gambling question was included in the survey in 2015).

- Further research and initiatives should focus on developing effective gender-specific public health interventions in order to prevent and reduce gambling-related harm.

motivations and the aetiology of problem gambling, ${ }^{23}$ yet most gambling research has been gender-blind, often giving only superficial treatment to women's gambling and related problems. ${ }^{4}$ The rapid expansion of gambling opportunities, both land-based and online, presents an increased risk for gambling problems among both women and men, and is thus an important area for research. ${ }^{3}$

Gambling participation, including gambling intensity (eg, gambling frequency, gambling expenditure, duration) and gambling versatility (ie, the number of game types gambled), has been associated with gambling problems. ${ }^{56}$ In addition, other game types such as electronic gaming machines (EGMs), casino games, poker, betting games, bingo and/or scratch games have also been linked with problem gambling. ${ }^{6-12}$ Earlier studies into gambling trends have shown only little interest in the role of different game 
types, but focused only on the proportion of individuals involved in gambling and on the frequency of problem gambling over a given period of time.

Earlier research has shown that there are certain gender-specific product preferences in gambling: women tend to play EGMs, bingo, scratch cards and lotteries, while men prefer table games, wagering and sport betting. ${ }^{3}$ There are also game type-specific perceptions of product harm across subgroups of women that have been addressed in recent studies. ${ }^{13}$ It has also been reported that some types of gambling venues were previously perceived as unattractive and stigmatising for women, ${ }^{1}$ but recently this has been changing with the development of modern venues and particularly the growth of online gambling, which have afforded greater anonymity and privacy. ${ }^{14}$ It seems that online gambling participation is increasing more rapidly among women than men, ${ }^{14}$ and that the risks of problem gambling for women in particular are greater than anticipated earlier. ${ }^{15}$

Motives for gambling also differ between men and women. Based on a recent Finnish population study, men tended to gamble more often for excitement, entertainment and for fun, while women gambled more often than men to win money. ${ }^{16} 17$ Women often gamble because it offers relief or escape from negative emotional states and boredom ${ }^{314}$; older women particularly cite the motive of escape. ${ }^{18}$ Based on a recent Finnish clinical survey, women gambled more often than men to escape. ${ }^{19}$ Men, on the other hand, tend to see gambling as a way of showing off their skills, a source of excitement or a possibility of striking it rich. ${ }^{3}$

Participation in gambling, gambling expenditure and the prevalence of gambling problems are still higher among men than women, both in Finland and elsewhere. ${ }^{20-24}$ In recent years, however, the gender gap in gambling-related problems has been narrowing. ${ }^{14}$ In Finland, women's occasional gambling increased from 2007 to 2011, specifically in two age groups, that is, 25-34 and 50-64 years. ${ }^{20}$ In 2015 , the overall prevalence of pastyear problem gambling was 3.3\%. From 2011 to 2015, this rate showed a tendency to increase among women. ${ }^{20} \mathrm{~A}$ similar trend has been observed in the UK, ${ }^{25}$ but not in Finland's western neighbour Sweden. ${ }^{26}$

The progression of gambling disorder ${ }^{27}$ also differs between women and men. On average women start to gamble and to develop gambling problems at a later age than men, ${ }^{28}$ but these problems develop into a fullblown disorder within a shorter period of time in women than in men, known as the 'telescoping effect'. ${ }^{29}$ There is consistent evidence to support such an effect in clinical samples, but not in a community-based sample. ${ }^{29}$

Gender differences in experienced harms have been narrowing as a result of the feminisation of gambling, ${ }^{3}$ highlighting the importance of investigating gender-specific trends using longitudinal data on men's and women's gambling participation. This study investigates gambling participation in more depth, looking at both gambling versatility (number of game types), gambling intensity (frequency) and gambling by different game types. In addition, we investigate trends in gambling severity by gender. This is the only viable path to creating a more effective gambling policy and a stronger public health orientation to harm reduction and the development of gender-specific treatments for those in need.

\section{Objective}

The aim of this study is to evaluate trends in past-year gambling participation and problem gambling severity in 2007, 2011 and 2015 among Finnish men and women. The assessments include game types played, gambling frequency and online gambling.

\section{METHODS}

\section{Sampling and procedure}

Our quantitative data consist of three cross-sectional random samples drawn from the Finnish population register in 2007, 2011 and 2015. The inclusion criteria were (1) age 15 years or over in 2007 and 15-74 years in 2011 and 2015; (2) Finnish or Swedish as mother tongue; and (3) resident of mainland Finland. Computer-assisted telephone interviews were obtained from 5008 participants in 2007, 4484 participants in 2011 and 4515 in 2015, with response rates of $58 \%, 40 \%$ and $62 \%$, respectively. In 2007 , the study was described to the potential participants as a 'gambling survey', and the data were collected by Taloustutkimus, a private market research company; in 2011 it was described as a 'gambling and health survey', and the data were again collected by Taloustutkimus; and in 2015 it was described as a 'gambling opinions and gambling survey', with the data collected by Statistics Finland. The data were weighted based on gender, age and region of residence in line with Statistics Finland's national population-based registers. For reasons of comparability, respondents over 74 were excluded from the 2007 data.

\section{Participant and public involvement}

Participants were not involved in the design or conduct of this study. There is no plan to disseminate to study participants.

\section{Setting}

Finland is heavily saturated with gambling opportunities and advertising. People have free access to international gambling sites online and to both land-based and online services provided by the government-regulated monopoly. In January 2017 the monopoly system was further strengthened with the merger of the three previously independent operators, that is, the Finnish Slot Machine Association (FSMA), Toto betting, and Veikkaus, the lottery and betting provider.

\section{Participants}

Data on respondents' gender (female, male) and age (recoded into age groups 15-17, 18-24, 25-34, 35-44, 45-54, 55-64 and 65-74) were obtained from the population register. 
Table 1 Past-year gambling versatility in 2007, 2011 and 2015

\begin{tabular}{|c|c|c|c|c|c|c|}
\hline & Year & $\mathbf{n}$ & $\geq 5$ gambling types & 3-4 gambling types & 1-2 gambling types & No gambling \\
\hline \multirow[t]{4}{*}{ All } & 2007 & 4722 & 12.4 (11.5 to 13.4$)$ & 20.6 (19.5 to 21.8$)$ & 40.4 (39.0 to 41.8$)$ & 26.6 (25.3 to 27.9$)$ \\
\hline & 2011 & 4484 & $10.0(9.1$ to 10.9$)$ & 20.5 (19.3 to 21.7$)$ & $47.2(45.7$ to 48.7$)$ & 22.3 (21.9 to 23.6$)$ \\
\hline & 2007-2011 & & $\begin{array}{l}\chi^{2}=13.287, d f=1, \\
p \leq 0.001\end{array}$ & $\begin{array}{l}\chi^{2}=0.014, d f=1 \\
p=0.906\end{array}$ & $\begin{array}{l}\chi^{2}=43.219, d f=1, \\
p \leq 0.001\end{array}$ & $\begin{array}{l}\chi^{2}=22.984, d f=1 \\
p \leq 0.001\end{array}$ \\
\hline & 2007-2015 & & $\begin{array}{l}\chi^{2}=5.810, d f=1 \\
p=0.016\end{array}$ & $\begin{array}{l}\chi^{2}=3.515, d f=1 \\
p=0.061\end{array}$ & $\begin{array}{l}\chi^{2}=10.947, d f=1, \\
p \leq 0.001\end{array}$ & $\begin{array}{l}\chi^{2}=56.129, d f=1 \\
p \leq 0.001\end{array}$ \\
\hline \multirow[t]{4}{*}{ Women } & 2007 & 2359 & $5.4(4.5$ to 6.4$)$ & 17.9 (16.4 to 19.5$)$ & 44.0 (42.0 to 46.1 ) & 32.7 (30.8 to 34.6$)$ \\
\hline & 2011 & 2367 & 3.5 (2.8 to 4.3$)$ & 17.6 (16.1 to 19.2$)$ & 51.5 (49.5 to 53.5$)$ & 27.4 (25.6 to 29.3$)$ \\
\hline & 2011-2015 & & $\begin{array}{l}\chi^{2}=18.216, d f=1 \\
p \leq 0.001\end{array}$ & $\begin{array}{l}\chi^{2}=3.643, d f=1 \\
p=0.056\end{array}$ & $\begin{array}{l}\chi^{2}=2.857, d f=1 \\
p=0.091\end{array}$ & $\begin{array}{l}\chi^{2}=3.694, d f=1 \\
p=0.055\end{array}$ \\
\hline & 2007-2015 & & $\begin{array}{l}\chi^{2}=1.339, d f=1 \\
p=0.247\end{array}$ & $\begin{array}{l}\chi^{2}=2.696, d f=1 \\
p=0.101\end{array}$ & $\begin{array}{l}\chi^{2}=11.467, d f=1 \\
p \leq 0.001\end{array}$ & $\begin{array}{l}\chi^{2}=33.759, d f=1 \\
p \leq 0.001\end{array}$ \\
\hline \multirow[t]{5}{*}{ Men } & 2007 & 2363 & 19.4 (17.8 to 21.1$)$ & 23.4 (21.7 to 25.2$)$ & 36.8 (34.9 to 38.8$)$ & $20.4(18.8$ to 22.1$)$ \\
\hline & 2011 & 2117 & 16.5 (14.9 to 18.2$)$ & 23.3 (21.5 to 25.2 ) & 43.0 (40.9 to 45.1$)$ & $17.1(15.5$ to 18.8$)$ \\
\hline & 2015 & 2305 & 22.0 (20.3 to 23.8 ) & 24.5 (22.8 to 26.3 ) & 38.5 (36.5 to 40.5$)$ & 15.0 (13.6 to 15.5$)$ \\
\hline & 2007-2011 & & $\begin{array}{l}\chi^{2}=6.353, d f=1 \\
p=0.012\end{array}$ & $\begin{array}{l}\chi^{2}=0.006, d f=1 \\
p=0.937\end{array}$ & $\begin{array}{l}\chi^{2}=17.921, d f=1, \\
p \leq 0.001\end{array}$ & $\begin{array}{l}\chi^{2}=3.665, d f=1 \\
p=0.056\end{array}$ \\
\hline & 2011-2015 & & $\begin{array}{l}\chi^{2}=21.371, d f=1 \\
p \leq 0.001\end{array}$ & $\begin{array}{l}\chi^{2}=0.873, d f=1 \\
p=0.350\end{array}$ & $\begin{array}{l}\chi^{2}=9.260, d f=1 \\
p=0.002\end{array}$ & $\begin{array}{l}\chi^{2}=3.619, d f=1 \\
p=0.057\end{array}$ \\
\hline
\end{tabular}

In \% (95\% Cl); percentages (\%) for weighted sample and sample sizes (n) for unweighted sample.

\section{Gambling types and versatility}

Participants were asked whether they had participated in 18 predefined gambling types (yes/no) during the past 12 months. Missing values and don't know responses were combined with the no category. These responses were also used to calculate the number of gambling types in which each participant had engaged during the past year (table 1). Some game types were combined for this analysis (see footnotes to tables 2 and 3 ).

\section{Gambling intensity}

Past-year gambling frequency was enquired for all gambling types in which the person had participated during the past year. A new variable was created to reflect overall gambling frequency. The response options were then recoded into five categories: no gambling, less than monthly, 1-3 times a month, once a week and several times a week (table 4). Participants who reported engaging in some form of online gambling during the past 12 months were classified as online gamblers, while the remaining gamblers were classified as strictly land-based gamblers. Online gambling has previously been operationalised in the same manner. ${ }^{15}$ The
2011 and 2015 interviews additionally included a dichotomous question concerning online gambling to ensure that no online gamblers went unidentified.

\section{Past-year gambling severity}

Past-year gambling severity was evaluated using the 20-item South Oaks Gambling Screen (SOGS), ${ }^{30}$ which reflects whether or not a person is likely to have a gambling problem. ${ }^{31}$ Reliability analyses of the Finnish version of the SOGS suggest two underlying dimensions: 'impact primarily on self' and 'impact on others as well'. This two-factor correlated factors model can be reinterpreted as a bifactor model with one general gambling-problem factor and two specific factors, with a similar interpretation as in the correlated factors model but with non-overlapping items. ${ }^{32}$ In this study, SOGS scores were recoded as the following: 0 (no gambling), 1-2 (at-risk gambling), 3-4 (problem gambling) and 5 or more (probable pathological gambling). Some concern has been expressed that SOGS may yield a high rate of false-positives in population studies, and overall the accuracy of the scale has been described as modest at best. ${ }^{33}$ 
Table 2 Past-year gambling of five most popular game types in 2007, 2011 and 2015

\begin{tabular}{|c|c|c|c|c|c|c|c|}
\hline & Year & $\mathbf{n}$ & Lottery games* & Scratch cards* & EGMs†‡ & $\begin{array}{l}\text { Daily lottery } \\
\text { games* }\end{array}$ & Betting games*§ \\
\hline \multirow[t]{4}{*}{ All } & 2007 & 4722 & 63.4 (62.0 to 64.8$)$ & 35.3 (33.9 to 36.7$)$ & 36.3 (34.9 to 37.7$)$ & $16.7(15.7$ to 17.8$)$ & 15.1 (14.1 to 16.2$)$ \\
\hline & 2015 & 4515 & 69.1 (67.7 to 70.5$)$ & 43.0 (41.6 to 44.5$)$ & 29.8 (28.5 to 31.2$)$ & 23.8 (22.6 to 25.1$)$ & $14.9(13.8$ to 16.0$)$ \\
\hline & 2007-2011 & & $\begin{array}{l}\chi^{2}=23.525, \mathrm{df}=1, \\
\mathrm{p} \leq 0.001\end{array}$ & $\begin{array}{l}\chi^{2}=1.013, d f=1 \\
p=0.314\end{array}$ & $\begin{array}{l}\chi^{2}=11.054, d f=1 \\
p=0.001\end{array}$ & $\begin{array}{l}\chi^{2}=1.616, d f=1 \\
p=0.204\end{array}$ & $\begin{array}{l}\chi^{2}=16.371, d f=1 \\
p \leq 0.001\end{array}$ \\
\hline & 2007-2015 & & $\begin{array}{l}\chi^{2}=33.504, d f=1, \\
p \leq 0.001\end{array}$ & $\begin{array}{l}\chi^{2}=57.483, d f=1, \\
p \leq 0.001\end{array}$ & $\begin{array}{l}\chi^{2}=44.018, d f=1, \\
p \leq 0.001\end{array}$ & $\begin{array}{l}\chi^{2}=72.251, d f=1, \\
p \leq 0.001\end{array}$ & $\begin{array}{l}\chi^{2}=0.072, d f=1 \\
p=0.788\end{array}$ \\
\hline \multirow[t]{3}{*}{ Women } & 2007 & 2359 & 59.9 (57.9 to 61.9$)$ & 35.6 (33.7 to 37.6 ) & 25.7 (24.0 to 27.5$)$ & $12.8(11.5$ to 14.2$)$ & 5.5 (4.6 to 6.5 ) \\
\hline & 2011-2015 & & $\begin{array}{l}\chi^{2}=0.842, d f=1 \\
p=0.359\end{array}$ & $\begin{array}{l}\chi^{2}=37.561, d f=1 \\
p \leq 0.001\end{array}$ & $\begin{array}{l}\chi^{2}=7.746, d f=1 \\
p=0.005\end{array}$ & $\begin{array}{l}\chi^{2}=34.432, d f=1, \\
p \leq 0.001\end{array}$ & $\begin{array}{l}\chi^{2}=0.259, d f=1 \\
p=0.611\end{array}$ \\
\hline & 2007-2015 & & $\begin{array}{l}\chi^{2}=12.642, d f=1 \\
p \leq 0.001\end{array}$ & $\begin{array}{l}\chi^{2}=42.829, d f=1 \\
p \leq 0.001\end{array}$ & $\begin{array}{l}\chi^{2}=35.233, d f=1 \\
p \leq 0.001\end{array}$ & $\begin{array}{l}X^{2}=52.560, d f=1 \\
p \leq 0.001\end{array}$ & $\begin{array}{l}\chi^{2}=3.512, d f=1 \\
p=0.061\end{array}$ \\
\hline \multirow[t]{4}{*}{ Men } & 2007 & 2363 & 67.0 (65.1 to 68.9$)$ & 35.0 (33.1 to 37.0 ) & 46.9 (44.9 to 48.9$)$ & 20.5 (18.9 to 22.2$)$ & 24.8 (23.1 to 26.6 ) \\
\hline & 2011 & 2117 & 72.7 (70.8 to 74.6$)$ & 32.4 (30.4 to 34.4 ) & 44.2 (42.1 to 46.4$)$ & 20.9 (19.2 to 22.7$)$ & 20.3 (18.6 to 22.1$)$ \\
\hline & 2015 & 2305 & 73.2 (71.3 to 75.0$)$ & 40.8 (38.8 to 42.8 ) & 41.3 (39.3 to 43.3 ) & 26.8 (25.0 to 28.7 ) & 25.5 (23.7 to 27.3$)$ \\
\hline & 2007-2011 & & $\begin{array}{l}\chi^{2}=17.172, d f=1 \\
p \leq 0.001\end{array}$ & $\begin{array}{l}\chi^{2}=3.374, d f=1 \\
p=0.066\end{array}$ & $\begin{array}{l}\chi^{2}=3.280, d f=1 \\
p=0.070\end{array}$ & $\begin{array}{l}\chi^{2}=0.109, d f=1 \\
p=0.741\end{array}$ & $\begin{array}{l}\chi^{2}=12.894, d f=1 \\
p \leq 0.001\end{array}$ \\
\hline
\end{tabular}

In \% $(95 \% \mathrm{Cl})$; percentages (\%) for weighted sample and sample sizes (n) for unweighted sample.

*Betting games provided by Veikkaus.

†Games provided by Finnish Slot Machine Association; all Veikkaus betting games were combined. $\ddagger 2007$ : scratch cards: online and paper-format combined.

$\S$ In 2015 data daily fast-paced and other daily lottery games were combined.

EGMs, electronic gaming machines.

\section{Data analysis}

Analyses were conducted using IBM SPSS Statistics V.22. CIs (95\% CIs) were calculated for all proportions and selected percentage point differences. Significance (p) between different time points was determined using $\chi^{2}$ tests. All temporal comparisons between the years 2007-2011, 2011-2015 and 2007-2015 were performed separately for all respondents aged 15-74 and for both genders.

\section{RESULTS}

\section{Gambling versatility}

Gambling participation in Finland increased by 6.6 percentage points (95\% CI 4.9 to 8.3) from 2007 to 2015 (table 1). During this period, playing one to two game types and five or more game types increased significantly.
Overall, gambling increased significantly among both women and men from 2007 to 2015 (table 1). From 2007 to 2011 , this increase was sharper among women (7.8 percentage points, $95 \%$ CI 5.5 to 10.4 ) than among men (5.4 percentage points, $95 \%$ CI 3.2 to 7.6 ). Playing one to two game types increased significantly in 2007-2011 among both genders. Among men, however, no change was seen in the proportion of those who played one to two game types in 2007-2015. The proportion of women who said they played five or more game types decreased in 2007-2011 and increased in 2011-2015. Therefore, the percentage of women who played five or more game types was unchanged over the period from 2007 to 2015. A similar pattern was observed for men: the proportion who reported gambling five or more game types decreased in 2007-2011 and increased significantly in 2011-2015, with 
Table 3 Past-year gambling of other game types in 2007, 2011 and 2015

\begin{tabular}{|c|c|c|c|c|c|c|c|c|}
\hline & Year & $\mathbf{n}$ & $\begin{array}{l}\text { Land-based casino } \\
\text { games* }\end{array}$ & Horse games $†$ & $\begin{array}{l}\text { Private betting/ } \\
\text { gambling }\end{array}$ & $\begin{array}{l}\text { Online } \\
\text { poker games }\end{array}$ & $\begin{array}{l}\text { Non-poker } \\
\text { games on FSMA } \\
\text { online casino§ }\end{array}$ & $\begin{array}{l}\text { Other non- } \\
\text { monopoly } \\
\text { games }\end{array}$ \\
\hline \multirow[t]{4}{*}{ All } & 2007 & 4722 & 9.6 (8.8 to 10.5$)$ & 5.5 (4.9 to 6.2$)$ & 6.0 (5.3 to 6.7$)$ & 3.1 (2.6 to 3.6 ) & NA & 2.8 (2.4 to 3.3 ) \\
\hline & 2015 & 4515 & 7.1 (6.4 to 7.9 ) & 5.5 (4.9 to 6.2 ) & 4.5 (3.9 to 5.2 ) & 3.1 (2.6 to 3.7 ) & 1.6 (1.3 to 2.0 ) & 3.8 (3.3 to 4.4 ) \\
\hline & $2007-2011$ & & $\begin{array}{l}\chi^{2}=22.379, d f=1, \\
p \leq 0.001\end{array}$ & $\begin{array}{l}\chi^{2}=0.00, d f=1 \\
p=1.000\end{array}$ & $\begin{array}{l}\chi^{2}=0.674, d f=1, \\
p=0.412\end{array}$ & $\begin{array}{l}\chi^{2}=1.155, d f=1, \\
p=0.283\end{array}$ & NA & $\begin{array}{l}\chi^{2}=0.00, d f=1 \\
p=1.000\end{array}$ \\
\hline & $2007-2015$ & & $\begin{array}{l}\chi^{2}=18.791, d f=1 \\
p \leq 0.001\end{array}$ & $\begin{array}{l}\chi^{2}=0.000, d f=1, \\
p=1.000\end{array}$ & $\begin{array}{l}\chi^{2}=0.984, d f=1, \\
p=0.321\end{array}$ & $\begin{array}{l}\chi^{2}=0.000, d f=1, \\
p=1.000\end{array}$ & NA & $\begin{array}{l}\chi^{2}=7.256, d f=1, \\
p=0.007\end{array}$ \\
\hline \multirow[t]{3}{*}{ Women } & 2007 & 2359 & 3.5 (2.8 to 4.3 ) & 3.1 (2.4 to 3.9 ) & 1.8 (1.3 to 2.4$)$ & 0.8 (0.5 to 1.3$)$ & NA & $0.9(0.6$ to 1.4$)$ \\
\hline & 2011-2015 & & $\begin{array}{l}\chi^{2}=16.596, d f=1 \\
p \leq 0.001\end{array}$ & $\begin{array}{l}\chi^{2}=0.327, d f=1, \\
p=0.568\end{array}$ & $\begin{array}{l}\chi^{2}=2.959, \mathrm{df}=1, \\
\mathrm{p}=0.085\end{array}$ & $\begin{array}{l}\chi^{2}=5.250, d f=1, \\
p=0.022\end{array}$ & $\begin{array}{l}\chi^{2}=1.372, d f=1, \\
p=0.241\end{array}$ & $\begin{array}{l}\chi^{2}=6.239, d f=1, \\
p=0.013\end{array}$ \\
\hline & 2007-2015 & & $\begin{array}{l}\chi^{2}=12.651, d f=1 \\
p \leq 0.001\end{array}$ & $\begin{array}{l}\chi^{2}=0.000, \mathrm{df}=1, \\
p=1.000\end{array}$ & $\begin{array}{l}\chi^{2}=3.882, d f=1, \\
p=0.049\end{array}$ & $\begin{array}{l}\chi^{2}=1.097, d f=1, \\
p=0.295\end{array}$ & NA & $\begin{array}{l}\chi^{2}=4.570, d f=1, \\
p=0.033\end{array}$ \\
\hline \multirow[t]{5}{*}{ Men } & 2007 & 2363 & $15.6(14.2$ to 17.1$)$ & 7.9 (6.8 to 9.1$)$ & 10.8 (9.6 to 12.1$)$ & 5.4 (4.5 to 6.4 ) & NA & 4.7 (3.9 to 5.6$)$ \\
\hline & 2011 & 2117 & 21.7 (20.0 to 23.5 ) & 7.5 (6.4 to 8.7$)$ & 9.5 (8.3 to 10.8$)$ & 6.5 (5.5 to 7.6 ) & 2.7 (2.1 to 3.5 ) & 4.7 (3.8 to 5.7 ) \\
\hline & 2015 & 2305 & 12.5 (11.2 to 13.9$)$ & 7.3 (6.3 to 8.4$)$ & $7.9(6.4$ to 9.1$)$ & 5.1 (4.2 to 6.1$)$ & 2.5 (1.9 to 3.2 ) & 6.0 (5.1 to 7.1$)$ \\
\hline & $2007-2011$ & & $\begin{array}{l}\chi^{2}=27.571, d f=1 \\
p \leq 0.001\end{array}$ & $\begin{array}{l}\chi^{2}=0.251, d f=1, \\
p=0.616\end{array}$ & $\begin{array}{l}X^{2}=2.062, d f=1 \\
p=0.151\end{array}$ & $\begin{array}{l}\chi^{2}=2.425, d f=1, \\
p=0.119\end{array}$ & NA & $\begin{array}{l}\chi^{2}=0.000, d f=1, \\
p=1.000\end{array}$ \\
\hline & 2011-2015 & & $\begin{array}{l}\chi^{2}=66.477, \mathrm{df}=1, \\
p \leq 0.001\end{array}$ & $\begin{array}{l}\chi^{2}=0.064, d f=1, \\
p=0.800\end{array}$ & $\begin{array}{l}X^{2}=3.568, d f=1, \\
p=0.059\end{array}$ & $\begin{array}{l}\chi^{2}=3.977, d f=1, \\
p=0.046\end{array}$ & $\begin{array}{l}\chi^{2}=0.175, d f=1, \\
p=0.676\end{array}$ & $\begin{array}{l}\chi^{2}=3.664, d f=1, \\
p=0.056\end{array}$ \\
\hline
\end{tabular}

In \% (95\% Cl); percentages (\%) for weighted sample and sample sizes ( $\mathrm{n}$ ) for unweighted sample.

${ }^{*}$ RAY Slot Machine Association.

†2007 and 2011: horse betting total.

$\ddagger$ Ålands Penningautomatförening's game (PAF) and online poker games internationally in 2007 and 2011 and also FSMA (2015) poker.

$\S$ Casino, casino games gambled outside of casino (roulette, blackjack) were combined.

FSMA, Finnish Slot Machine Association; NA, non-applicable.

the net effect that the proportion of men playing five or more game types increased between 2007 and 2015. No significant change or gender differences were observed in the proportions who played three to four game types.

\section{Type of games}

Lottery games, scratch cards and EGMs were the top three most popular gambling types among both women and men in 2007-2015 (table 2). Lottery games and scratch cards gained increased popularity among all respondents regardless of gender between 2007 and 2015. For lottery games this upward trend was already seen in 2007-2011, while for scratch cards the trend came later, that is, from 2011 to 2015. Playing daily lottery games also increased from 2007 to 2015. Playing EGMs, by contrast, decreased among both genders during the period under examination. Participation in betting games decreased in 20072011 but increased in 2011-2015.
Land-based casino gambling increased from 2007 to 2011 among men, but decreased from 2007 to 2015 among both women and men (table 3 ). Betting specifically on horses was unchanged, while privately arranged betting decreased consistently over the 9-year period. Online poker increased in popularity among women between 2011 and 2015, but decreased in popularity among men during the same period. No significant changes were seen from 2007 to 2015.

An item enquiring about playing non-poker games on the FSMA's online casino was first included in the 2011 survey. Gambling on the FSMA online casino was unchanged from 2011 to 2015. On the other hand, playing other non-monopoly games increased from 2007 to 2015 among all respondents, regardless of gender. In 2015, another new item enquiring about gambling on cruise ships sailing between Finland and Sweden and Finland and Estonia was included for the 
Table 4 Past-year gambling intensity in 2007, 2011 and 2015

\begin{tabular}{|c|c|c|c|c|c|c|c|}
\hline & Year & $\mathbf{n}$ & $\begin{array}{l}\text { Several times a } \\
\text { week }\end{array}$ & Once a week & $\begin{array}{l}\text { 1-3 times a } \\
\text { month }\end{array}$ & $\begin{array}{l}\text { Rarely than } \\
\text { monthly }\end{array}$ & Do not gamble \\
\hline \multirow[t]{6}{*}{ All } & 2007 & 4722 & $11.0(10.1$ to 11.9$)$ & 29.8 (28.5 to 31.1$)$ & 18.2 (17.1 to 19.3$)$ & 14.4 (13.4 to 15.4$)$ & 26.6 (25.3 to 27.9$)$ \\
\hline & 2011 & 4484 & 9.5 (8.7 to 10.4$)$ & 26.2 (24.9 to 27.5 ) & 20.8 (19.6 to 22.0$)$ & 21.5 (20.3 to 22.7 ) & 22.1 (20.9 to 23.3) \\
\hline & 2015 & 4515 & 8.9 (8.1 to 9.8$)$ & 25.1 (23.8 to 26.4 ) & 22.7 (21.5 to 24.0$)$ & 23.3 (22.1 to 24.6 ) & 20.0 (18.4 to 21.2$)$ \\
\hline & 2007-2011 & & $\begin{array}{l}\chi^{2}=5.615, d f=1 \\
p=0.018\end{array}$ & $\begin{array}{l}\chi^{2}=14.769, d f=1, \\
p \leq 0.001\end{array}$ & $\begin{array}{l}\chi^{2}=9.916, d f=1 \\
p=0.002\end{array}$ & $\begin{array}{l}\chi^{2}=79.029, d f=1, \\
p \leq 0.001\end{array}$ & $\begin{array}{l}\chi^{2}=25.240, d f=1, \\
p \leq 0.001\end{array}$ \\
\hline & 2011-2015 & & $\begin{array}{l}\chi^{2}=0.970, d f=1 \\
p=0.325\end{array}$ & $\begin{array}{l}\chi^{2}=1.427, d f=1 \\
p=0.232\end{array}$ & $\begin{array}{l}\chi^{2}=4.771, d f=1 \\
p=0.029\end{array}$ & $\begin{array}{l}\chi^{2}=4.193, d f=1 \\
p=0.041\end{array}$ & $\begin{array}{l}\chi^{2}=5.970, d f=1 \\
p=0.015\end{array}$ \\
\hline & 2007-2015 & & $\begin{array}{l}\chi^{2}=11.335, d f=1, \\
p \leq 0.001\end{array}$ & $\begin{array}{l}\chi^{2}=25.568, d f=1, \\
p \leq 0.001\end{array}$ & $\begin{array}{l}\chi^{2}=28.780, d f=1, \\
p \leq 0.001\end{array}$ & $\begin{array}{l}\chi^{2}=119.993, d f=1, \\
p \leq 0.001\end{array}$ & $\begin{array}{l}\chi^{2}=56.377, d f=1, \\
p \leq 0.001\end{array}$ \\
\hline \multirow[t]{6}{*}{ Women } & 2007 & 2359 & 6.2 (5.3 to 7.3$)$ & 25.2 (23.5 to 27.0$)$ & $17.4(15.9$ to 19.0$)$ & 18.5 (17.0 to 20.1 ) & 32.7 (30.8 to 34.6 ) \\
\hline & 2011 & 2367 & 4.5 (3.7 to 5.4$)$ & 20.8 (19.2 to 22.5$)$ & 19.1 (17.5 to 20.7$)$ & 28.4 (26.6 to 30.3 ) & 27.0 (25.2 to 28.8$)$ \\
\hline & 2015 & 2210 & 5.2 (4.3 to 6.2$)$ & 20.7 (19.0 to 22.5 ) & 18.5 (16.9 to 20.2 ) & 30.7 (28.8 to 32.7$)$ & 24.9 (23.1 to 26.7$)$ \\
\hline & 2007-2011 & & $\begin{array}{l}\chi^{2}=6.743, d f=1, \\
p=0.009\end{array}$ & $\begin{array}{l}\chi^{2}=12.914, \mathrm{df}=1, \\
p=0.009\end{array}$ & $\begin{array}{l}\chi^{2}=2.288, d f=1 \\
p=0.130\end{array}$ & $\begin{array}{l}\chi^{2}=64.479, d f=1, \\
p \leq 0.001\end{array}$ & $\begin{array}{l}\chi^{2}=18.330, d f=1, \\
p \leq 0.001\end{array}$ \\
\hline & 2011-2015 & & $\begin{array}{l}\chi^{2}=1.216, d f=1 \\
p=0.270\end{array}$ & $\begin{array}{l}\chi^{2}=0.007, d f=1, \\
p=0.934\end{array}$ & $\begin{array}{l}\chi^{2}=0.269, \mathrm{df}=1 \\
\mathrm{p}=0.604\end{array}$ & $\begin{array}{l}\chi^{2}=2.906, d f=1 \\
p=0.088\end{array}$ & $\begin{array}{l}20 \mathrm{df}=1 \\
6\end{array}$ \\
\hline & 2007-2015 & & $\begin{array}{l}\chi^{2}=2.117, \mathrm{df}=1, \\
p=0.146\end{array}$ & $\begin{array}{l}\chi^{2}=13.035, \mathrm{df}=1, \\
p \leq 0.001\end{array}$ & $\begin{array}{l}\chi^{2}=0.938, d f=1 \\
p=0.333\end{array}$ & $\begin{array}{l}\chi^{2}=92.045, d f=1, \\
p \leq 0.001\end{array}$ & $\begin{array}{l}\chi^{2}=33.759, \mathrm{df}=1, \\
\mathrm{p} \leq 0.001\end{array}$ \\
\hline \multirow[t]{6}{*}{ Men } & 2007 & 2363 & 15.8 (14.4 to 17.3$)$ & 34.6 (32.7 to 36.6 ) & 19.0 (17.4 to 20.6$)$ & 10.3 (9.1 to 11.6$)$ & 20.4 (18.8 to 22.1$)$ \\
\hline & 2011 & 2117 & $14.5(13.0$ to 16.1$)$ & 31.5 (29.5 to 33.5 ) & 22.4 (20.6 to 24.2 ) & 14.5 (13.0 to 16.1$)$ & 17.1 (15.5 to 18.8$)$ \\
\hline & 2015 & 2305 & 12.6 (11.3 to 14.0$)$ & 29.5 (27.6 to 31.4 ) & 26.9 (25.1 to 28.8$)$ & 16.0 (14.5 to 17.6$)$ & 15.0 (13.6 to 16.5$)$ \\
\hline & 2007-2011 & & $\begin{array}{l}X^{2}=1.465, d f=1 \\
p=0.226\end{array}$ & $\begin{array}{l}\chi^{2}=4.842, d f=1 \\
p=0.028\end{array}$ & $\begin{array}{l}\chi^{2}=7.888, d f=1 \\
p=0.005\end{array}$ & $\begin{array}{l}\chi^{2}=18.275, \mathrm{df}=1, \\
\mathrm{p}<0.001\end{array}$ & $\begin{array}{l}\chi^{2}=7.951, d f=1 \\
p=0.005\end{array}$ \\
\hline & 2011-2015 & & $\begin{array}{l}\chi^{2}=3.409, d f=1 \\
p=0.065\end{array}$ & $\begin{array}{l}\chi^{2}=2.083, d f=1 \\
p=0.149\end{array}$ & $\begin{array}{l}\chi^{2}=11.997, d f=1, \\
p<0.001\end{array}$ & $\begin{array}{l}\chi^{2}=1.917, d f=1, \\
p=0.166\end{array}$ & $\begin{array}{l}\chi^{2}=3.619, d f=1, \\
p=0.057\end{array}$ \\
\hline & 2007-2015 & & $\begin{array}{l}\chi^{2}=9.793, \mathrm{df}=1, \\
p=0.002\end{array}$ & $\begin{array}{l}\chi^{2}=13.925, \mathrm{df}=1, \\
\mathrm{p} \leq 0.001\end{array}$ & $\begin{array}{l}\chi^{2}=41.235, \mathrm{df}=1, \\
\mathrm{p} \leq 0.001\end{array}$ & $\begin{array}{l}\chi^{2}=33.263, d f=1, \\
p \leq 0.001\end{array}$ & $\begin{array}{l}\chi^{2}=23.317, d f=1 \\
p \leq 0.001\end{array}$ \\
\hline
\end{tabular}

In \% (95\% Cl); percentages (\%) for weighted sample and sample sizes (n) for unweighted sample.

first time, and therefore analysed separately. In 2015, 11 percentage points (women $1.1 \%$, men $14.5 \%$ ) of the respondents said they had gambled on cruise ships.

\section{Gambling intensity}

Gambling one to three times a month and less often than once a month showed a tendency to increase among all respondents. By contrast, gambling once a week or several times a week decreased from 2007 to 2011 and also from 2007 to 2015 (table 4). Gambling less often than monthly increased significantly among both women and men from 2007 to 2011, and also from 2007 to 2015 (table 4). Gambling one to three times a month increased only among men. Gambling once a week decreased from 2007 to 2011 and also from 2007 to 2015 in both genders. In general, intensity of gambling increased for both genders starting 2007-2011. Overall, online gambling increased significantly between 2011 and 2015 among both women and men.

\section{Gambling severity}

Non-problem gambling (SOGS=0) increased clearly from 2007 to 2011 and from 2007 to 2015 among all respondents, regardless of gender. At-risk gambling (SOGS=1-2) increased among women from 2011 to 2015, but decreased among men from 2007 to 2011. Problem gambling (SOGS=3-4) also increased among women in 2011-2015, although no significant changes were seen over the longer time frame (2007-2015). Likewise, there were no significant changes in probable pathological gambling (SOGS $\geq 5$ ) (table 5).

\section{DISCUSSION}

Our data show that gambling participation has increased among both men and women in Finland in 2007-2015. This conflicts with recent evidence from the UK, for instance. ${ }^{25}$ Our data also demonstrate that women's gambling increased from 2007 to 2011. A similar trend was observed in the UK. ${ }^{25}$ 


\begin{tabular}{|c|c|c|c|c|c|c|}
\hline Year & $\mathbf{n}$ & No gambling & SOGS $=0$ & SOGS $=1-2$ & SOGS $=3-4$ & SOGS $\geq 5$ \\
\hline 2007 & 4722 & 26.5 (25.3 to 27.8$)$ & 55.2 (53.8 to 56.6$)$ & $15.2(14.2$ to 16.3$)$ & 2.1 (1.7 to 2.6$)$ & $1.0(0.7$ to 1.3$)$ \\
\hline 2015 & 4515 & 20.0 (18.8 to 21.2 ) & 61.7 (60.3 to 63.1$)$ & 15.0 (14.0 to 16.1$)$ & 2.0 (1.6 to 2.5 ) & 1.3 (1.0 to 1.7$)$ \\
\hline 2007-2011 & & $\begin{array}{l}\chi^{2}=24.165, d f=1, \\
p \leq 0.001\end{array}$ & $\begin{array}{l}\chi^{2}=42.512, d f=1 \\
p \leq 0.001\end{array}$ & $\begin{array}{l}\chi^{2}=6.784, d f=1 \\
p=0.009\end{array}$ & $\begin{array}{l}\chi^{2}=1.969, d f=1 \\
p=0.161\end{array}$ & $\begin{array}{l}\chi^{2}=0.000, d f=1 \\
p=1.000\end{array}$ \\
\hline 2007-2015 & & $\begin{array}{l}\chi^{2}=54.524, d f=1 \\
p \leq 0.001\end{array}$ & $\begin{array}{l}\chi^{2}=40.129, d f=1, \\
p \leq 0.001\end{array}$ & $\begin{array}{l}\chi^{2}=0.072, d f=1 \\
p=0.788\end{array}$ & $\begin{array}{l}\chi^{2}=0.115, d f=1 \\
p=0.735\end{array}$ & $\begin{array}{l}\chi^{2}=1.832, d f=1 \\
p=0.176\end{array}$ \\
\hline 2007 & 2359 & 32.6 (30.7 to 34.5$)$ & 55.3 (53.3 to 57.3$)$ & 10.5 (9.3 to 11.8$)$ & 0.9 (0.6 to 1.4) & 0.7 (0.4 to 1.1$)$ \\
\hline 2011-2015 & & $\begin{array}{l}\chi^{2}=2.872, d f=1 \\
p=0.090\end{array}$ & $\begin{array}{l}\chi^{2}=1.401, \mathrm{df}=1 \\
\mathrm{p}=0.237\end{array}$ & $\begin{array}{l}\chi^{2}=7.725, \mathrm{df}=1 \\
\mathrm{p}=0.005\end{array}$ & $\begin{array}{l}\chi^{2}=9.997, d f=1 \\
p=0.002\end{array}$ & $\begin{array}{l}\chi^{2}=2.324, d f=1 \\
p=0.127\end{array}$ \\
\hline 2007-2015 & & $\begin{array}{l}\chi^{2}=32.933, d f=1 \\
p \leq 0.001\end{array}$ & $\begin{array}{l}\chi^{2}=15.765, d f=1 \\
p \leq 0.001\end{array}$ & $\begin{array}{l}\chi^{2}=1.406, d f=1 \\
p=0.236\end{array}$ & $\begin{array}{l}\chi^{2}=2.527, d f=1 \\
p=0.112\end{array}$ & $\begin{array}{l}\chi^{2}=1.225, \mathrm{df}=1 \\
\mathrm{p}=0.268\end{array}$ \\
\hline 2007 & 2363 & 20.3 (18.7 to 22.0 ) & 55.0 (53.0 to 57.0$)$ & 20.0 (18.4 to 21.7$)$ & 3.3 (2.6 to 4.1$)$ & $1.3(0.9$ to 1.8$)$ \\
\hline 2011 & 2117 & 17.1 (15.5 to 18.8$)$ & 61.0 (58.9 to 63.1$)$ & 17.6 (16.0 to 19.3$)$ & 3.0 (2.3 to 3.8$)$ & 1.4 (0.9 to 2.0$)$ \\
\hline 2015 & 2305 & 15.1 (13.7 to 16.6$)$ & 62.3 (60.3 to 64.3$)$ & 18.4 (16.8 to 20.0$)$ & 2.6 (2.0 to 3.3 ) & 1.6 (1.1 to 2.2$)$ \\
\hline 2007-2011 & & $\begin{array}{l}\chi^{2}=7.492, d f=1 \\
p=0.006\end{array}$ & $\begin{array}{l}\chi^{2}=16.480, d f=1 \\
p \leq 0.001\end{array}$ & $\begin{array}{l}\chi^{2}=4.201, d f=1 \\
p=0.040\end{array}$ & $\begin{array}{l}\chi^{2}=0.329, d f=1 \\
p=0.567\end{array}$ & $\begin{array}{l}\chi^{2}=0.084, d f=1 \\
p=0.772\end{array}$ \\
\hline
\end{tabular}

In \% (95\% Cl); percentages (\%) for weighted sample and sample sizes (n) for unweighted sample. SOGS, South Oaks Gambling Screen.

There are indications internationally of an ongoing feminisation of gambling: increasing numbers of women are gambling, showing an interest in online gambling, ${ }^{34}$ developing gambling problems and seeking help for gambling-related problems. ${ }^{3}$ In Finland one possible explanation for this trend could lie in women's increasingly lenient attitudes towards gambling. ${ }^{35}$ Another contributing factor might lie in the launch of both online and land-based games specifically tailored to women. It has been reported that women regard online gambling as less stigmatising and as a more convenient gambling environment. ${ }^{36}$

In Finland, it has earlier been reported that occasional gambling is on the rise among women in their $30 \mathrm{~s}$ and $50 \mathrm{~s} .{ }^{19}$ On the other hand, women's weekly gambling appears to be declining. Furthermore, playing one to two game types appears to be increasing both among men and particularly among women. Lottery games, scratch cards and daily lottery games have all gained increasing popularity among both men and women. There is similar evidence from the UK. ${ }^{25}$ However, the clearest gender difference in game type preferences is seen in scratch card gambling, which is more popular among Finnish women than men based on both population and clinical studies. ${ }^{16} 1719$

EGMs, on the other hand, have declined in popularity over the past decade. Our data also show some variation in playing betting games, which decreased during the first 5-year period but then turned to an upward trajectory. These fluctuating trends in playing different game types and in the popularity of specific game types suggest that in the Finnish context at least, there have been changes in the supply and marketing of gambling opportunities, including the introduction of new games (eg, daily lotteries) and games that foster 'gamblers' fallacy' and other gambling-related irrational beliefs. The growth of gambling on non-monopoly sites is possibly a reflection of the increased availability and access to new games and game sites internationally.

Recently women have shown a growing interest in both online poker and land-based casino games, traditionally male-dominated types of gambling. ${ }^{26}$ In Finland a similar trend has been found among treatment-seeking gamblers, 
with young men and young women reporting similar gambling profiles focused on competitive gambling. ${ }^{37}$ Our data showed that EGMs have declined in popularity among Finnish men and women during the past decade. As Griffiths ${ }^{38}$ has suggested, it is possible that these EGM gamblers have now gone online. Gambling online is flexible, available 24/7 and minimises the fear of becoming stigmatised. $^{39}$ Another possible explanation for this decline in popularity lies in the stricter regulations put in place in Finland in 2010-2011, when the legal age for gambling was raised to 18 years.

EGMs have nonetheless been the number one reason, for both men and women, for calling the gambling helpline ever since it was launched in Finland in 2004, ${ }^{12} 40$ which is in line with reports from New Zealand. ${ }^{41}$ The reason why EGM gambling is on the decline at the population level but still the main cause of problems possibly lies in the growth of online EGM gambling. People who play EGMs online probably often play other games as well. In the future it is important to closely monitor specific game types (ie, EGMs) that are linked with problematic gambling and harms ${ }^{10} 1142$ and are typically gambled at a high intensity, ${ }^{6}$ not forgetting the gender aspect, as suggested by McCarthy and colleagues. ${ }^{13}$

Our results show that men's and women's online gambling increased from 2011 to 2015. This is in line with previous findings for women in particular. ${ }^{25}$ In Finland, the number of helpline calls concerning female online gambling increased from 2007 to $2009 .^{40}$ Furthermore, there is evidence from a clinical context that the proportion of those who only gambled online is higher among women $(25 \%)$ than men $(8 \%) .{ }^{19}$ On the other hand, men gambled more $(65 \%)$ than women $(41 \%)$ both online and land-based. Online gambling in particular is a cause for some concern, since in 2017 about half of all calls to the gambling helpline were from people who gambled primarily online and $56 \%$ had used loans or payday loans to finance their gambling. Overall, high gambling-related debts are usually connected with fast-paced online gambling. ${ }^{12}$ Future research should more closely explore gender differences in specific game types gambled online and their relation to harm.

It has been suggested that women gamble online for different reasons than men. ${ }^{14}$ They seem to be more susceptible to advertising messages than men, and more often gamble on websites their friends have tried. Moreover, it has been reported that women are attracted to online gambling by their offers of free trial games. ${ }^{14} \mathrm{~A}$ recent study from Finland also suggests that women may be at higher risk of spending more money on online gambling than men. ${ }^{15}$ Younger generations are probably first and foremost attracted to online gambling by its convenience, social acceptability, and their own knowledge and familiarity with technology. ${ }^{43}$ As far as older women are concerned, it has been reported that gaming providers' marketing efforts are increasingly designed to target these particular age groups. ${ }^{43}$
Our study provides no explanation for women's increased online gambling in Finland. It is therefore paramount to explore in more detail the effects of marketing and advertising, particularly in the current climate which has seen women adopt a more lenient attitude towards gambling. ${ }^{35}$ McCormack et $a l^{14}$ have also called on policymakers to look more closely at the impact of gambling advertising. In order to develop more effective public health policies, the authorities need to closely monitor the constantly changing scenes of gambling both in Finland and elsewhere.

Gambling severity showed widely varying trends between men and women. In 2011-2015, both at-risk and problem gambling increased sharply among women; there were also indications of a possible slight rise in pathological gambling. Among men, the trend was quite the opposite in 2007-2011. First, it may be that women are more susceptible to advertising and therefore more openly trying out new games than men. A second possible explanation lies in the marked increase in the availability of different games that are specifically favoured by women, such as fast and slow land-based lotteries and slot-type online games and online scratch cards and bingos. Third, given women's increasingly lenient attitudes towards gambling in $2011-2015,{ }^{35}$ and given the positive association of such attitudes with intentions to gamble, this climate may have contributed to normalise gambling among women in particular. Fourth, women have reported that a gambling environment where they felt important ${ }^{44}$ may have contributed to increase their gambling in Finland. Fifth, women may have more irrational beliefs related to gambling (eg, beating the casino or feeling lucky). ${ }^{44}$ Sixth, it is possible that women face greater barriers than men to seeking help (eg, longer distances, higher costs, lack of information, as well as internal barriers such as denial of the problem, fear, ambivalence, stigma, shame and a sense of being misunderstood, or lack of knowledge on the part of health professionals about the nature of gambling problems), ${ }^{46-48}$ which may serve to exacerbate the problem. Seventh, it is possible that while men have already adapted to increased gambling exposure, women's gambling is only just beginning to grow and expand. From the clinical context, it is noteworthy to mention that reported gambling harms (eg, gambling debts and loans) had two peaks first in 2010-2012 and second in 2015-2016. ${ }^{40}$

The growth of women's at-risk and problem gambling is not reflected in contacts with helplines, however. In 2005-2016, the proportion of calls coming from men to the Finnish helpline has remained steadily at around $70 \%-80 \%$. It seems that early on, most female callers were older women, but more recently the share of younger women has been rising. ${ }^{40}$ Among treatment-seeking problem gamblers at a Finnish gambling clinic, the age curve for male patients peaks at 27 years and then falls off, while for female patients there is one peak at age 26 and a second one at age 50. Treatment registers support the assumption regarding the telescoping effect: for almost half of all women, problem gambling develops in the space of less than 2 years. Furthermore, among 
treatment-seeking problem gamblers, women under 30 have the most severe gambling disorders, while for men the lowest scores are recorded for those over $50 .^{39}$

At the population level it seems that women's gambling problems have been on the rise, at least recently, but among help-seeking gamblers it is not the number of female problem gamblers seeking help that has been changing, but rather their age breakdown. ${ }^{14}$ Women in their 30 s tend to play the same games as men in the same age bracket, and they also have the most severe gambling disorders. At the population level, men and women seem to differ from each other based on their gambling participation, including gambling frequency, gambling expenditure and gambling versatility (the number of game types gambled) ${ }^{16}$ However, a clinical survey indicates that there are no such gender differences among help-seeking gamblers. ${ }^{19}$ The number of helpline calls is now on the rise, ${ }^{12}$ which highlights the importance of continued monitoring of gambling and gambling problems in Finland.

Future studies must therefore tackle the feminisation of gambling from the perspectives of age, generation and socioeconomic background. Furthermore, qualitative studies have drawn attention to the earlier, adolescent onset of gambling among younger women and the impact of family problems (eg, alcohol abuse, mental health problems) on female gamblers' life and loneliness particularly among older women. ${ }^{49}$ Also, as it seems that the growth of female problem gambling is not reflected in the help-seeking sample, it is clearly important that the threshold to seeking help is kept as low as possible. As discussed earlier by Castrén and colleagues, ${ }^{50} 51$ it is important that future research investigates the existence of gender-specific barriers to seeking help.

This study provides a valuable estimate of how Finnish people's gambling behaviour has changed over the past decade. It does have some limitations, though. Direct comparisons between the different data sets are not possible because they were collected by different organisations. The main difference between these two organisations is that Statistics Finland, the official national statistical agency, is more effective in reaching prospective participants and so generates higher response rates than the private market research company Taloustutkimus. Also, the data were collected at different times of the year (the data in 2007 and 2015 were collected in the spring and in 2011 in late autumn), which may also explain the differences between the response rates. The description of a survey as a 'gambling survey' may contribute to creating sampling bias by instigating greater participation among people who gamble and who are interested in the topic. ${ }^{52}$ Some items (eg, questions on FSMA online casino gambling and cruise ship gambling) were not included in the survey until 2011, making it impossible to identify trends: this would require taking a longer time perspective, which is something we intend to do in our future studies. In addition, recall bias and social desirability bias are always risks in self-reported surveys. It should also be noted that we chose to use the standard SOGS cut-off score of 5 or more rather than 4 , which may produce better results, but this lower cut-off point has not been used or validated in Finland. Also, as pointed out by Goodie and colleagues, ${ }^{53}$ it is noteworthy that SOGS, specifically with the scores that we used, has some limitations when compared with the diagnostic criteria of the Diagnostic and Statistical Manual of Mental Disorders, 5th Edition. ${ }^{27}$

\section{CONCLUSIONS}

Our results indicate that while gambling is still very much a male preserve, women's gambling participation and problem gambling have recently increased in Finland. Observations from gambling treatment facilities do not indicate an increase in the number of contacts from women, but rather that a new group of younger women with serious gambling problems has emerged. The feminisation of gambling may thus be a matter of age as much as it is a matter of gender. It is paramount that effective age-specific and gender-specific public health measures are put in place in primary prevention (eg, increasing awareness and knowledge about different game types) and secondary prevention (eg, maintaining and improving effective low threshold services and both online and face-to-face treatment services) so that gambling-related harms can be prevented or mitigated and so that vulnerable and high-risk groups can be adequately protected.

Contributors All named authors made substantial contributions to this study and article. SC and AHS were responsible for the study conception and design; AHS performed the analysis; $\mathrm{SC}$ and $\mathrm{MH}$ conducted the literature searches and summarised the previous research; SC, $\mathrm{MH}$ and AHS were responsible for data interpretation; SC, MH and AHS drafted and prepared the manuscript. All authors read and approved the final version.

Funding The Ministry of Social Affairs and Health, Helsinki, Finland, provided funding for this research (appropriation under section 52 of the Lotteries Act).

Competing interests None declared.

Patient consent Not required.

Ethics approval The Ethics Committee of the National Institute for Health and Welfare approved the research protocol (statement: THL/1122/6.02.01/2014). The ethical principles of the Declaration of Helsinki and its amendments or comparable ethical standards were followed.

Provenance and peer review Not commissioned; externally peer reviewed.

Data sharing statement Finnish gambling data sets are available for research purposes from the Finnish Social Science Data Archive (http://www.fsd.uta.fi/en/).

Open access This is an open access article distributed in accordance with the Creative Commons Attribution Non Commercial (CC BY-NC 4.0) license, which permits others to distribute, remix, adapt, build upon this work non-commercially, and license their derivative works on different terms, provided the original work is properly cited, appropriate credit is given, any changes made indicated, and the use is non-commercial. See: http://creativecommons.org/licenses/by-nc/4.0/.

\section{REFERENCES}

1. Delfabbro PH. Australasian gambling review. 5th edn. Adelaide: Independent Gambling Authority, 2012.

2. Hing N, Russell A, Tolhard B, et al. A comparative study of men and women gamblers in Victoria. Victoria, Australia: Victorian Responsible Gambling Foundation, 2014. (accessed 06 Jul 2016).

3. Holdsworth L, Hing N, Breen H. Exploring women's problem gambling: a review of the literature. Int Gambl Stud 2012;12:199-213. 
4. Svensson J, Romild U, Nordenmark M, et al. Gendered gambling domains and changes in Sweden. Int Gamb/ Stud 2011;11:193-211.

5. LaPlante DA, Nelson SE, LaBrie RA, et al. Disordered gambling, type of gambling and gambling involvement in the British Gambling Prevalence Survey 2007. Eur J Public Health 2011;21:532-7.

6. Binde P, Romild U, Volberg RA. Forms of gambling, gambling involvement and problem gambling: evidence from a Swedish population survey. Int Gamb/ Stud 2017;17:490-507.

7. Dowling N, Smith D, Thomas T. Electronic gaming machines: are they the 'crack-cocaine' of gambling? Addiction 2005;100:33-45.

8. Binde P. What are the most harmful forms of gambling? Analyzing problem gambling prevalence surveys. CEFOS Working Paper $2011 ; 12$

9. Afifi TO, Cox BJ, Martens PJ, et al. The relation between types and frequency of gambling activities and problem gambling among women in Canada. Can J Psychiatry 2010;55:21-8.

10. Abbott M, Stone CA, Billi R, et al. Gambling and problem gambling in Victoria, Australia: Changes over 5 years. J Gamb/ Stud 2016;32:47-78.

11. Castrén S, Perhoniemi R, Kontto J, et al. Associaton between gambling involvement by game type and gambling harms: Finnish population study. Int Gambl Stud 2017:124-42.

12. Silvennoinen I, Sjöholm M, Vuorento $\mathrm{H}$, et al. Peluuri's annual report 2017. 2017. https://peluuri.fi/sites/default/files/peluuri_vuosiraportti_ 2017_lopullinen_24.4.2018.pdf

13. McCarthy S, Thomas SL, Randle M, et al. Women's gambling behaviour, product preferences, and perceptions of product harm: differences by age and gambling risk status. Harm Reduct $J$ 2018:15:22.

14. McCormack A, Shorter GW, Griffiths MD. An empirical study of gender differences in online gambling. J Gamb/ Stud 2014;30:71-88.

15. Edgren R, Castrén $\mathrm{S}$, Alho $\mathrm{H}$, et al. Gender comparison of online and land-based gamblers from a nationally representative sample: Does gambling online pose elevated risk? Comput Human Behav 2017;72:46-56.

16. Salonen AH, Latvala T, Castrén $\mathrm{S}$, et al. Rahapelaaminen, rahapelihaitat ja rahapelien markkinointiin liittyvät mielipiteet Uudellamaalla, Pirkanmaalla ja Kymenlaaksossa [Gambling Harms Survey 2016. Gambling, gambling-related harm and opinions on gambling marketing in Uusimaa, Pirkanmaa and Kymenlaakso]: Report 9/2017. Helsinki, Finland: National Institute for Health and Welfare (THL), 2016.

17. Salonen $\mathrm{AH}$, Hellman M, Latvala $\mathrm{T}$, et al. Gambling participation, gambling habits, gambling-related harm, and opinions on gambling advertising in Finland in 2016. Nord Stud Alcohol Dr 2018;35:215-34.

18. Tarras J, Signh A, Moufakkir $O$. The profile and motivations of elderly women gamblers. UNLV Gam Res Rev J 2012;5:3.

19. Salonen AH, Castrén S, Latvala T, et al. Rahapelaaminen, rahapelihaitat ja rahapelien markkinointiin liittyvät mielipiteet rahapeliongelmaan apua hakevilla Peliklinikan asiakkailla [Gambling Harms Survey 2016. Gambling, gambling-related harm and opinions on gambling marketing among Gambling Clinic clients]: Report 8/2017. Helsinki, Finland: National Institute for Health and Welfare (THL), 2016.

20. Salonen A, Raisamo S. Suomalaisten rahapelaaminen 2015 Rahapelaaminen, rahapeliongelmat ja rahapelaamiseen liittyvät asenteet ja mielipiteet 15-74-vuotiailla. [Finnish gambling 2015. Gambling, gambling problems, and attitudes and opinions on gambling among Finns aged 15-74]: Report 16/2015. Helsinki: National Institute for Health and Welfare (THL), 2015.

21. Productivity Commission. Gambling. Inquiry Report, No. 50. Canberra: ACT, 2010.

22. Abbott M, Bellinger ME, Garrett N, et al. New Zealand 2012 national gambling study: overview and gambling participation. Wellington: Ministry of Health, 2014.

23. Sproston K, Hing N, Palankay C. Prevalence of gambling in new South Wales. Sydney: NSW office of Liquor, Gaming and Racing, 2012.

24. Gambling commission. Gambling participation in 2016: behaviour awareness and attitudes. Birmingham, England: Gambling Comission, 2017

25. Wardle $\mathrm{H}$, Sproston $\mathrm{K}$, Orford J, et al. British gambling prevalence survey 2007. Nat Cen 2007. http://www.gamblingcommission.gov. uk/pdf/britsh\%20gambling\%20prevalence\%20survey\%202007\% 20-\%20sept\%202007.pdf

26. Romild U, Svensson J, Volberg R. A gender perspective on gambling clusters in Sweden using longitudinal data. Nord Stud Alcohol Dr 2016;33:43-60.

27. American Psychiatric Association. Diagnostic and statistical manual of mental disorders- DSM-5. Washington, D.C: American Psychiatric Association, 2013.
28. Grant JE, Odlaug BL, Mooney ME. Telescoping phenomenon in pathological gambling: association with gender and comorbidities. $J$ Nerv Ment Dis 2012;200:996.

29. Slutske WS, Piasecki TM, Deutsch AR, et al. Telescoping and gender differences in the time course of disordered gambling: evidence from a general population sample. Addiction 2015;110:144-51.

30. Lesieur HR, Blume SB. The South Oaks Gambling Screen (SOGS): a new instrument for the identification of pathological gamblers. Am J Psychiatry 1987;144:1184-8.

31. Abbott MW, Volberg RA. The measurement of adult problem and pathological gambling. Int Gamb/ Stud 2006;6:175-200.

32. Salonen AH, Rosenström T, Edgren R, et al. Two dimensions of the South Oaks Gambling Screen among Finnish population sample. Scand J Psychol 2017;58:228-37.

33. Williams RJ, Volberg RA. The classification accuracy of four problem gambling assessment instruments in population research. Int Gamb/ Stud 2014;14:15-28.

34. Gainsbury S, Parke J, Suhonen N. Consumer attitudes towards Internet gambling: Perceptions of responsible gambling policies, consumer protection, and regulation of online gambling sites. Comput Human Behav 2013;29:235-45.

35. Salonen AH, Alho H, Castrén S. Attitudes towards gambling, gambling participation, and gambling-related harm: cross-sectional Finnish population studies in 2011 and 2015. BMC Public Health 2017; 17:122.

36. Hing N, Nuske E, Gainsbury SM, et al. Perceived stigma and selfstigma of problem gambling: perspectives of people with gambling problems. Int Gambl Stud 2016;16:31-48.

37. Jaakkola T, Paasio P. Pelaajan profiili - Peliklinikan avohoidon asiakaskunnasta nousevia havaintoja [Gambler's profile Observations from Gambling Clinic]. In: Jaakkola T, ed. Peliklinikka 2010-2014. Loppuraportti [Gambling Clinic 2010-2014-Final Report, 2015. (accessed 01 Sep 2017).

38. Griffiths M. Internet gambling: preliminary results of the first U.K. prevalence study. J Gamb Issue 2001;9.

39. Gainsbury SM. Online gambling addiction: the relationship between internet gambling and disordered gambling. Curr Addict Rep 2015;2:185-93

40. Pajula M, Sjöholm M, Vuorento H. Peluuri vuosiraportti, 2015-2016 [Peluuri Annual Report, 2015-2016]. 2016. https://peluuri.fi/sites/default/ files/peluuri_vuosiraportti_2015-2016_0.pdf (accessed 1 Sep 2017).

41. Kim HS, Hodgins DC, Bellringer M, et al. Gender differences among helpline callers: prospective study of gambling and psychosocial outcomes. J Gambl Stud 2016;32:605-23.

42. MacLaren VV. Video lottery is the most harmful form of gambling in Canada. J Gamb/ Stud 2016;32:459-85.

43. Griffths MD. Technological trends and the psychological impact on gambling. Cas Gam Int 2011;7:77-80.

44. Baxter A, Salmon C, Dufresne K, et al. Gender differences in felt stigma and barriers to help-seeking for problem gambling. Addict Behav Rep 2016;3:1-8.

45. Hing N, Russell A, Tolchard B, et al. Risk factors for gambling problems: an analysis by gender. J Gamb/ Stud 2016;32:511-34.

46. Suurvali $\mathrm{H}$, Cordingley J, Hodgins DC, et al. Barriers to seeking help for gambling problems: a review of the empirical literature. $J$ Gambl Stud 2009;25:407-24.

47. Gainsbury S, Hing N, Suhonen N. Professional help-seeking for gambling problems: awareness, barriers and motivators for treatment. J Gamb/ Stud 2014;30:503-19.

48. Kaufman A, Jones Nielsen JD, Bowden-Jones H. Barriers to treatment for female problem gamblers: a UK perspective. J Gambl Stud 2017;33:975-91.

49. Subramaniam $M$, Wang $P$, Soh $P$, et al. Prevalence and determinants of gambling disorder among older adults: a systematic review. Addict Behav 2015;41:199-209.

50. Castrén S, Alho H, Salonen A. rahapeliongelma sosiaali - ja terveyden huollossa - ammattilaisten näkemyksiä. [Beliefs and opinions of social and health care professionals with respect to problem gambling]. Yhteiskuntapolitiikka 2016;81:418-28.

51. Castrén S, Salonen AH, Alho H, et al. Rahapeliongelmaisten hoito vielä hajanaista. (Services for problem gamblers in Finland). Suomen Lääkärilehti 2015;70:650-5.

52. Williams RJ, Volberg RA, Stevens RMG. The population prevalence of problem gambling: methodological influences, standardized rates, jurisdictional differences, and worldwide trends: report prepared for the Ontario problem gambling research centre and the ontario ministry of health and long term care, 2012.

53. Goodie AS, MacKillop J, Miller JD, et al. Evaluating the South Oaks Gambling screen with DSM-IV and DSM-5 criteria: results from a diverse community sample of gamblers. Assessment 2013;20:523-31. 